\title{
TELEGRAM MESSENGER BOT FOR REALTIME MINE OPERATION REPORTS
}

\author{
Reza Ardhianto
}

Mine Technical Services Department, PT. Amman Mineral Nusa Tenggara

\begin{abstract}
ABSTRAK
Informasi realtime sangat penting untuk mendukung kegiatan operasional di tambang Batu Hijau PT. Amman Mineral Nusa tenggara. Selama ini salah satu metode yang digunakan dalam pendistribusian informasi realtime adalah dengan menggunakan MORS SMS Broadcaster yang telah dikembangkan oleh seksi Fleet Management System \& Data Analyst yang memanfaatkan layanan GSM Short Message Service (SMS) dari operator seluler. Namun seiring dengan bertambahnya informasi yang harus diberikan dan semakin banyak jumlah pengguna layanan tersebut menjadikan pendistribusian informasi menggunakan SMS semakin tidak efektif dari sisi biaya. Keterbatasan dari sisi format pesan jumlah karakter yang dapat dikirimkan menggunakan layanan SMS juga semakin menurunkan kualitas informasi yang dapat diberikan. Untuk mengatasi kekurangan yang ada di sistem sebelumnya, perlu dikembangkan sistem/layanan baru dalam pendistribusian informasi realtime yang lebih efisien dari sisi biaya dan dapat meningkatkan kualitasi informasi yang disampaikan. Dari perbandingan terhadap beberapa alternatif aplikasi yang sejenis, Telegram dipilih untuk digunakan dalam pengembangan sistem baru karena lebih unggul dalam beberapa parameter perbandingan yang telah ditetapkan. Penggunaan fitur Telegram Bot juga telah memberikan dampak signifikan terhadap efisiensi biaya dan kualitas informasi laporan yang diberikan untuk mendukung kegiatan operasional dalam menjaga dan meningkatkan produktivitas tambang.
\end{abstract}

Kata Kunci : informasi realtime, Short Message Service, Telegram, Bot, produktivitas tambang

\begin{abstract}
Realtime information is very important to support operational activities at PT. Amman Mineral Nusa Tenggara's Batu Hijau mine. One of the methods used in the distribution of realtime information is to use MORS SMS Broadcaster which has been developed by the Fleet Management System \& Data Analyst section that utilizes GSM Short Message Service (SMS) services from cellular operators. But along with the increase in information that need to be provided and the increasing number of users of these service makes the distribution of information using SMS increasingly ineffective in terms of cost. Limitations in message format and the number of characters that can be sent in a single SMS also further degrades the quality of information that can be provided. To overcome the weaknesses that exist in the previous system, new systems / services need to be developed to distribute realtime information that is more efficient in terms of cost and can improve the quality of information delivered. From a comparison of several similar application alternatives, Telegram was chosen for use in the development of a new system because it was superior in a number of predetermined comparison parameters. The use of the Telegram Bot feature has also had a significant impact on the cost efficiency and quality of report information delivery to support operational activities in maintaining and increasing mine productivity.
\end{abstract}

Keywords : realtime information, Short Message Service, Telegram, Bot, mine productivity 


\section{A. INTRODUCTION}

Batu Hijau is an open pit mining site located in West Sumbawa District of West Nusa Tenggara Province. The location can be reached by $75 \mathrm{KM}$ road trip from Mataram city and then continued by speed boat for an hour. In 2016 Batu Hijau was acquired by a consortium led by PT Amman Mineral Internasional which subsequently changes the name of Batu Hijau mine-concession holder from PT Newmont Nusa Tenggara to become PT Amman Mineral Nusa Tenggara (PTAMNT).

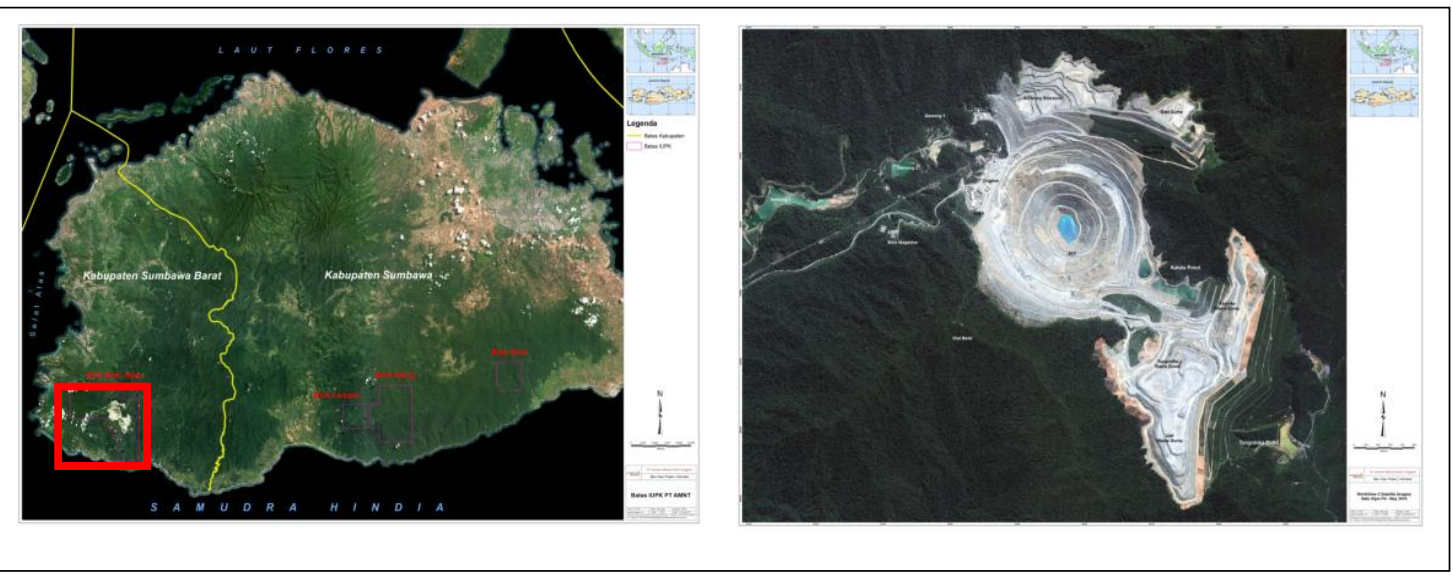

Picture 1. Batu Hijau Pit Location

PTAMNT operates more than a hundred of heavy equipment units for earthmoving activities in Mine Operation department. Most of it has Jigsaw MineOPS Fleet Management System installed to manage assignments/activities and collects operational data to be processed and presented through MORS, an in-house developed datawarehouse and reporting system. Registered users can access MORS to monitor various KPIs and other production related information through company intranet portal, email subscription and smartphone/mobile devices.

One of the service provided by MORS since 2010 is SMS Broadcaster which can distribute report/notifications to subscribers through GSM Short Message Service (SMS). Information such as hourly production, down shovel \& drill notification, heavy equipment unit problem related to WiFi / GPS devices, etc. can be sent both on realtime or on specific recurring time schedule. MORS SMS Broadcaster plays an important role to support Mine Operation in order to get realtime actual data for faster data-driven decision making to either maintain or improve overall mine productivity. For example, realtime unscheduled down equipment notification will help the mechanics to get early information and faster response to provide corrective maintenance and minimize downtime that can affect equipment productivity.

\section{A.1. Problem Statement}

Over time the amount of information distributed via MORS SMS Broadcaster is getting more detailed so that sometimes a single report must be sent separately in multiple messages due to limited number of characters that can be sent in a single SMS (160 characters). The limited number of characters and SMS format that can only send flat-text also affects the ease to quickly understand the information sent compared to rich-text format that can include emoji, formatted font (Bold, Italic, Underline), images, etc..

The monthly costs of telecommunications bills also slowly increasing along with increasing number of subsribers, more detailed and frequent information sent. According to telecommunications facilities usage by department report (distributed by the IT Department), the usage of MORS SMS Broadcaster in March 2019 cost more than USD 700.00 ( \pm Rp. 10,000,000, ). 
For these reasons, it is really necessary to develop new ways of distributing information from MORS to mobile devices that are more cost-efficient without reducing or can actually improve the quality of the delivered information and also compatible with the existing and future infrastructure and systems upgrades.

\section{A.2. Requirement}

Based on the problem statement, the solution to be developed must meet some predetermined criteria so that in addition to solving the problem at hand it can also provide added values. The new Broadcaster system to be developed must meet the following criterias :

- Utilize recent technology stack but must maintain compatibility with existing and future infrastructure or systems development \& upgrades plan.

- Minimal system development and operational costs.

- Improve delivered information quality.

Requirement analysis also conducted based on discussions with the users to gather their impression about the existing system and constructive feedbacks for the new system development.

\section{B. SYSTEM ANALYSIS}

\section{B.1. MORS (Mine Operation Reporting System)}

MORS is a datawarehouse and reporting system based on Microsoft SQL Server Business Intelligence platform that has been in-house developed in PTAMNT since 2008. As a Datawarehouse/Business Intelligence system, MORS connect, clean and integrates (ETL - Extract, Transform \& Loading) data from multiple different datasources into multidimensional datamarts grouped by each specific business process (Load \& Haul, Drilling, Blasting, Equipment States, etc.).

The output products and services of MORS includes realtime dashboards, historical static reports, OLAP Cube/Excel pivot table, XML reports and SMS report/notification broadcast. Existing MORS architecture is described on the picture below.

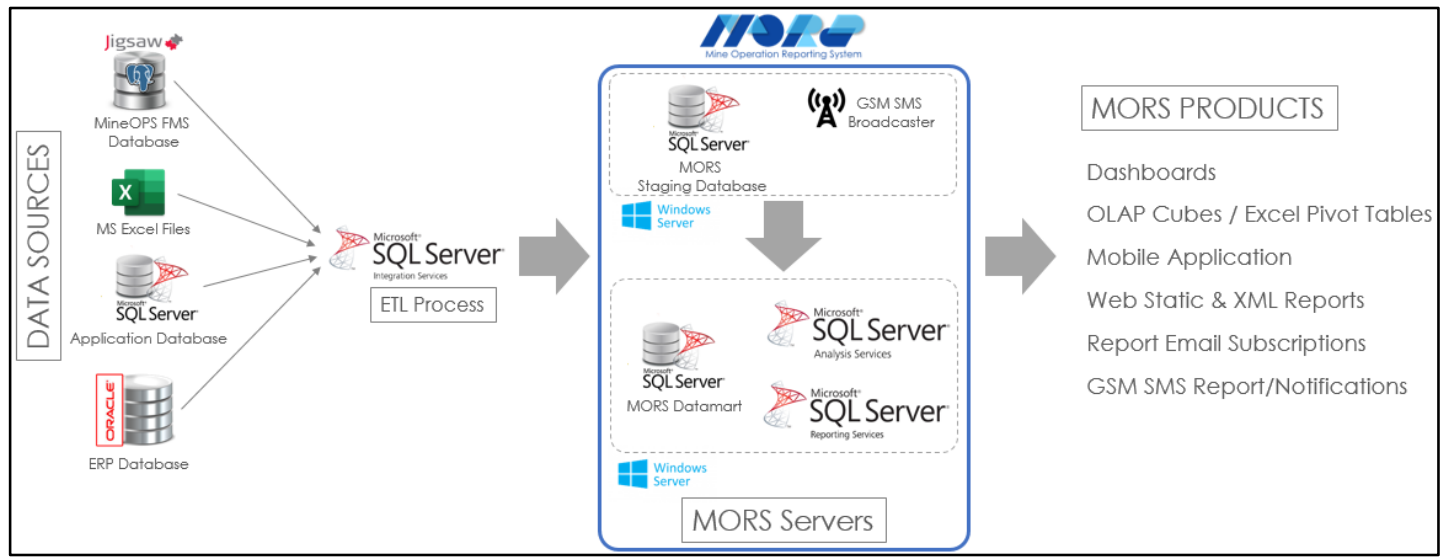

Picture 2. MORS Architecture

Current MORS infrastructure include :

- 2 Dell PowerEdge (R710 \& R910) Windows Servers

- Microsoft SQL Server, includes :

- SQL Server Database Engine

- SQL Server Integration Service

- SQL Server Analysis Service

- SQL Server Reporting Service 
- $\quad$ IIS Web Service

- NodeJS Web Service

\section{B.2. Messaging Application}

Messaging application are modern application or platform that enable messaging using internet connection, many which started around social network platforms but many of which have now developed into broad platforms enabling status updates, chatbots, and payments. Some examples of popular messaging applications include Whatsapp, WeChat, Viber, Line, Google Hangouts, Telegram, Snapchat, Microsoft Kaizala, etc.

Messaging application feature list and the number of user base as well as several other parameters will be used to determine which applications will be used for the development of the new broadcaster system. The results of several messaging application assessments that has been conducted can be seen in Table 1.

Table 1. Messaging Application Assessment

\begin{tabular}{clcccccc}
\hline No & Application & $\begin{array}{c}\text { User } \\
\text { Base }\end{array}$ & $\begin{array}{c}\text { Bot } \\
\text { API/SDK }\end{array}$ & Encryption & Compatibility* & $\begin{array}{c}\text { Rich Text } \\
\text { Format }\end{array}$ & Advertising \\
\hline 1 & Whatsapp & 5 & Yes** & Yes & 1 & Yes & No \\
2 & Microsoft Kaizala & 1 & Yes & Yes & 5 & Yes (Limited) & No \\
3 & Telegram & 3 & Yes & Yes & 4 & Yes & No \\
4 & Line & 3 & Yes & Yes & 4 & Yes & Yes \\
\hline
\end{tabular}

Point Range : 1 (Worst) - 5 (Best)

* Bot API / SDK Compatibility with existing infrastructure \& systems

** Need to register \& reviewed before get access to Bot API / SDK

The assessment data on Table 1 obtained from each official application vendor's website. Based on the assessment results, there are 2 applications that looks prominent, but advertisement that exists on Line platform is the weak point that makes Telegram finally chosen to be use in the new MORS Broadcaster System development.

\section{B.3. Telegram}

Telegram is a free cloud-based messaging and VoIP (Voice over Internet Protocol) application that can run on various operating systems such as Windows, MacOS, Linux, Android and IOS. In March 2018 Telegram had reached more than 200 million monthly active users.

One of the features provided by Telegram is Bot API (Application Programming Interface) which can be used to programmatically and automatically send messages to channel, group or specific registered users that interact with the bot. Telegram Bot API support almost all Telegram features that can be used manually by users including sending multimedia message (image, file, documents), group members management, etc.

In security aspect, every message sent using the Telegram service will be automatically end-to-end encrypted so that security in every information exchange process is guaranteed. $3^{\text {rd }}$ party service/application can be registered to get Telegram access token, and then utilize Telegram Bot API via internet to broadcast messages and receive/process feedbacks with Telegram clients (Channel, Group or User) who have given the Bot privilege to interact.

\section{B.4. MORS - Telegram Bot API Integration}

Telegram Bot API uses standard HTTP protocol to communicate so that it is relatively easy to use and integrate with MORS which already has NodeJS based web service backends. The new broadcaster service will be built using Javascript and running on NodeJS server utilizing existing services including :

- Authentication \& Authorization API 
User authentication service connected to corporate Active Directory server and manage application/service authorization handled by MORS Manager application.

- Data API

Data conversion service from SQL Server database query input to JSON output.

- NodeJS Proxy Service

Proxy service to act as a gateway for all incoming client request and routing/redirect to the requested backend service.

The service integration between MORS and Telegram Bot API can be seen on Picture 3.

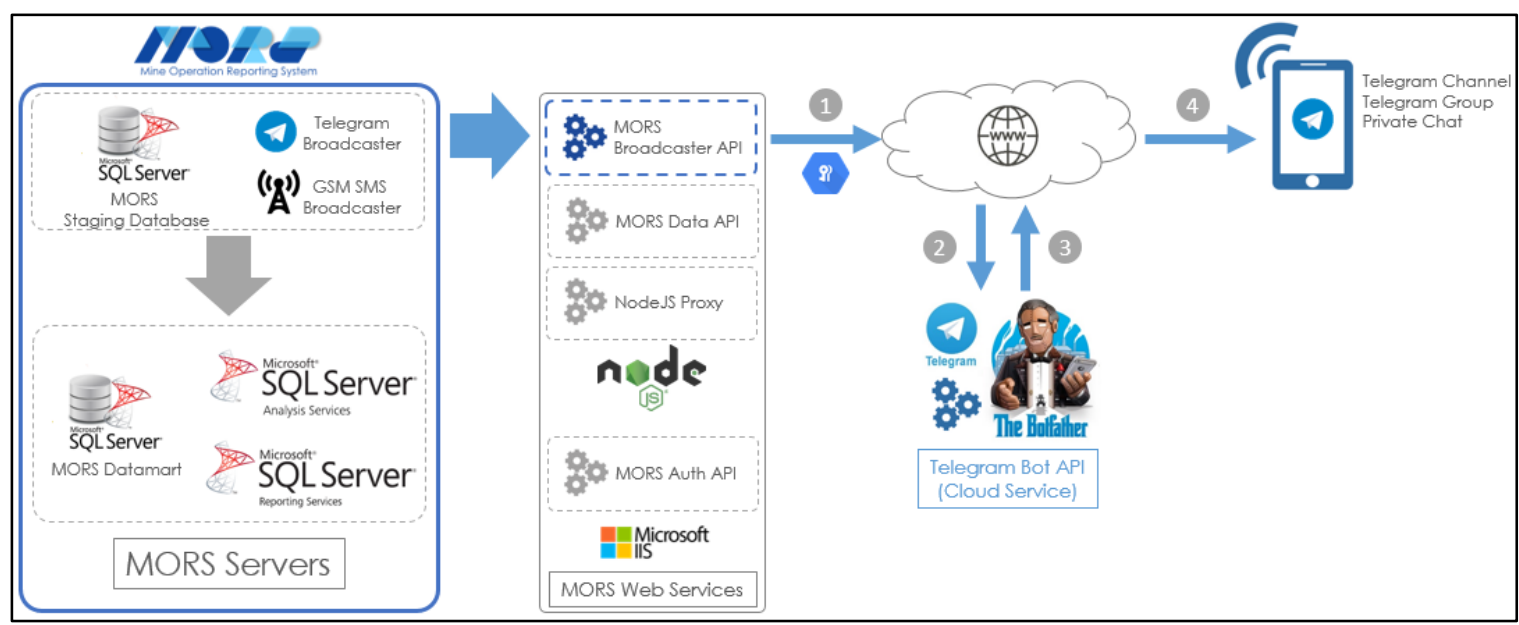

Picture 3. MORS - Telegram Bot API Integration

Most of the existing report database queries still use on the new system with some modification to utilize data format that were previously not supported by SMS (emoji, bold, italic font, etc). MORS Broadcaster service will manage list of information topic/reports and it's subscribers in database. The delivery schedule (realtime or recurring time schedule) also will be defined for each report/information subscription that will be used by service daemon to determine when report will be sent to the subscribers.

Report and notification scheduling is handled by SQL Server Integration Service which make system maintenance easier and more reliable because it uses the same platform with the main Reporting System (MORS) rather than relying on $3^{\text {rd }}$ party custom application and hardware as used by SMS Broadcaster.

\section{RESULTS}

To date, there are about 20 report topics created and sent to 8 MORS Telegram channels that have been categorized by several segments (by department, section and report contents) :

- Mining Alliance Channel (General)

$>$ Hourly Production Summary

$>$ Daily Total Production Summary

$>$ Daily Reports (Reports in .pdf file format released by Mine Engineering)

$>$ Weekly Mine Plan

$>$ Daily Blasting Radius

- Drill \& Blast Channel

$>$ Hourly Drill Performance

- Mine Maintenance Channel

$>$ Daily PM Compliance Report

- Down Equipment (Shovel \& Drill) Report Channel 
$>$ Realtime Down Equipment Notification

$>$ Down Equipment $>1$ Hour

$>$ Down Equipment $>2$ Hours

$>$ Down Equipment $>4$ Hours

- Up \& Down Equipment (Shovel \& Drill) Report Channel

$>$ Realtime Down Equipment Notification

$>$ Realtime Up Equipment Notification

- Mine To Crusher Report Channel

- Equipment Status Report Channel

- MORS Administrator Channel

System Warning \& Error Notifications.

Comparison between information sent using SMS broadcaster with the new MORS Broadcaster System and some new report that have been developed can be seen in the Picture 4.

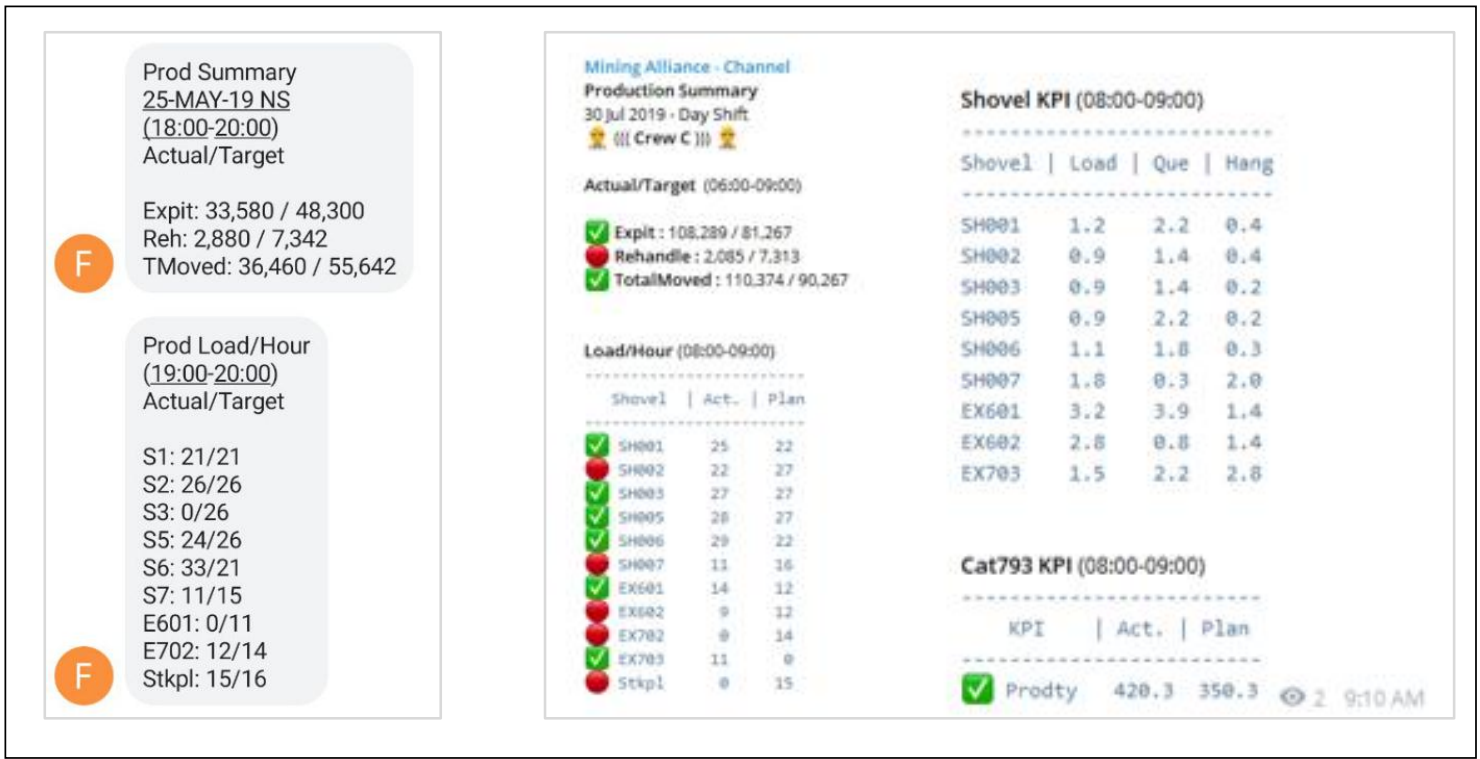

Picture 4. Production Summary - SMS (Left) vs Telegram (Right)

Example of Down Equipment information with GPS coordinates attached that can be opened on Google Map application can be seen in the Picture 5.

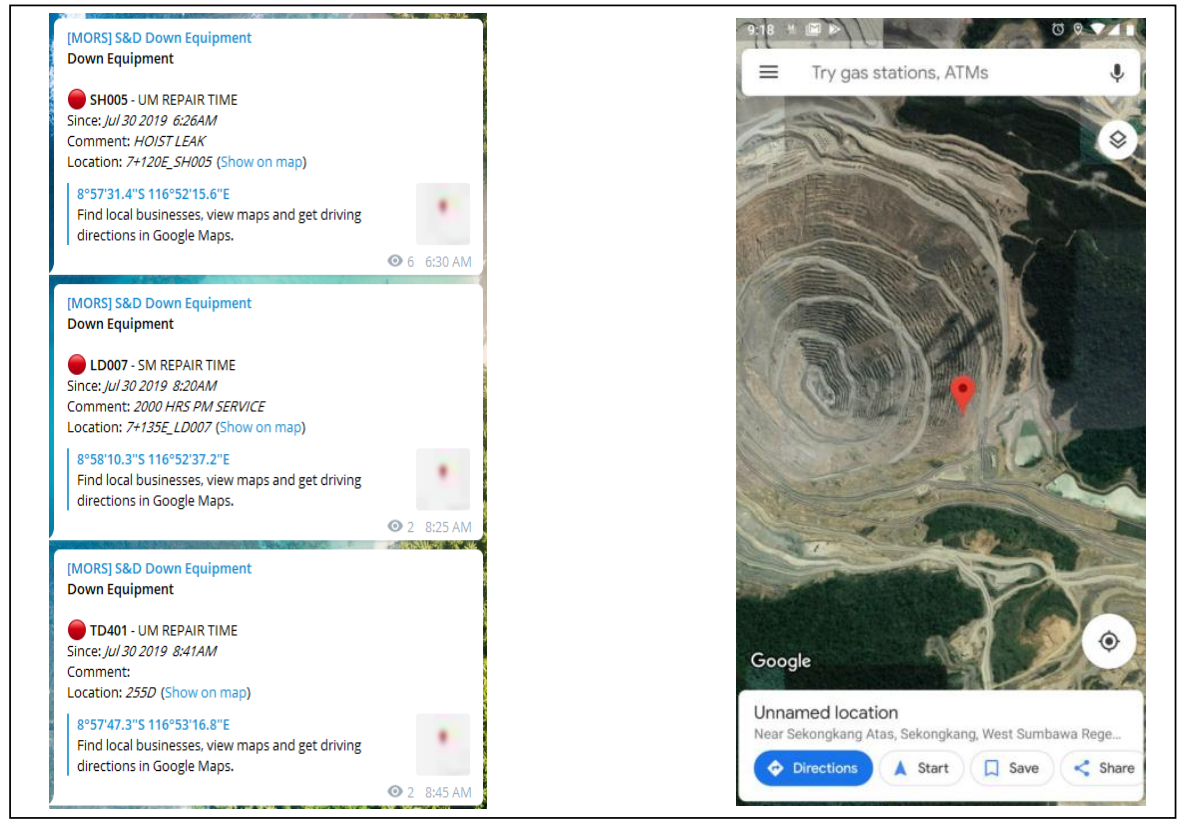


Picture 5. Telegram Down Equipment Notification With GPS Coordinates.

Daily reports distribution in pdf file format also have been implemented on can be seen on Picture 6.

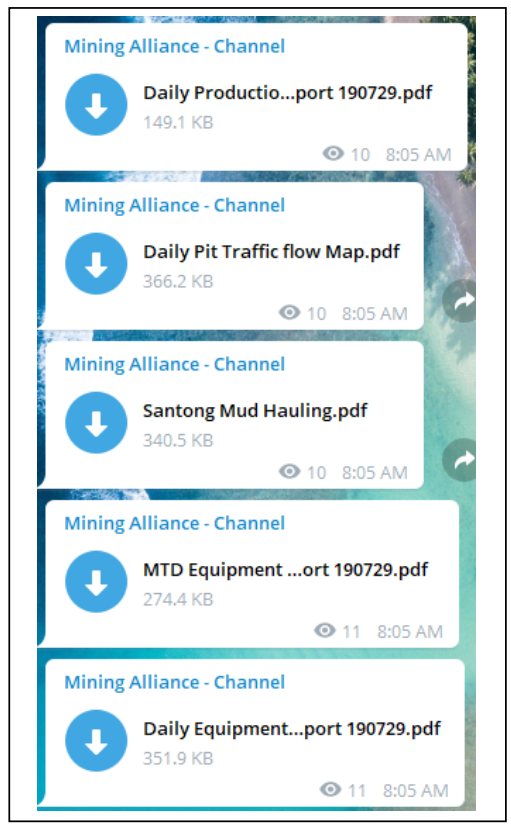

Picture 6. Telegram PDF File Distribution

Some notable objectives and improvements that have been achieved with the development and implementation of new MORS Broadcaster system are :

- 53\% (US\$ 392.07) monthly bills decrease on the first month of implementation (April) compared to March bills, then again declined sharply in the second month of implementation (May) by $91 \%$ (US\$ 677.61) and in the third month (June) by $98 \%$ (US\$ 727.33) compared to March bills.

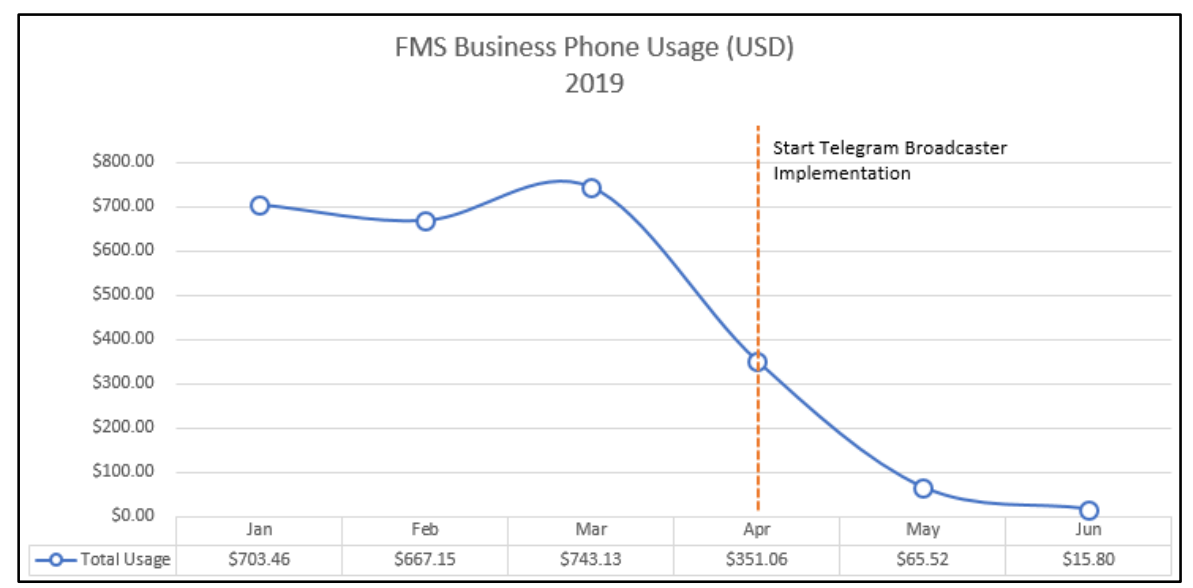

Picture 7. FMS Telecomunication Usage (US\$)

Using June monthly bills (after full implementation) as a reference for yearly calculation, the estimated total savings that can be done in a year with the new system are:

US\$727.33 X 12 months $=$ US\$ 8,727.90 
- $\quad$ There are no additional costs incurred in the process of developing \& implementing of this new system because the software used is Free \& Open Source with MIT license, utilize company's broadband internet connection, and infrastructure / hardware that already exists and has been used by MORS.

- SMS has a maximum limit of 160 characters in a single message, while the maximum limit in Telegram message is 4096 characters so that the information sent can be more detailed.

- Messages sent via SMS are limited to flat text only (cannot be formatted), while Telegram supports the UTF-8 which support various character formats (bold, italic, emoji, etc.) so that information is faster and easier to understand by the recipients.

- Telegram supports multimedia files (PDF, MS Office, JPEG, PNG, etc.), so files like Daily Report, Weekly Mine Plan, Blasting Radius Notification etc. also can be distributed easily. This feature is very useful for employees who do not have access to corporate email through mobile devices, because the report files distributed via Telegram use PDF format so that it is easy to access / read using standard applications on smartphones.

- Telegram supports message containing map coordinate link that can be opened automatically using Google Map application. It is very useful for displaying information related to the actual location of heavy equipment unit (e.x.: Down Shovel \& Drill unit notification with actual location coordinates attached) so that maintenance crew can spot the actual location of the unit that requires repair/service with faster response.

- Telegram has a group chat / channel feature so that the distribution of information can be easily grouped by topic and user segment (by department, section, specific report topic, etc.). This feature can also minimize the use of internet bandwidth because sending information to many users only needs to be done once based on group / channel even though the number of members registered in it is very large.

\section{CONCLUSION}

The development of the new Broadcaster MORS system has fulfilled the objectives that have been set, and even opened new opportunities to develop more advanced features utilizing Telegram Bot API such as on-demand reports, chatbots etc. This system also provides some added values for the company, not only in of mine productivity but also in work safety perspective that have been shown on implementation of Blasting Radius Notification.

\section{ACKNOWLEDGEMENT}

All information contained in this paper is the personal view of the authors and do not reflect any policy or view of PTAMNT. This paper is intended for educational purposes only. No copyright violation intended, and any source have been adequately quoted.

Some of the information reported here was also obtained from internal reports and are reproduced with the kind permission of PTAMNT's management

\section{REFERENCES}

IT Department (2019), Telephone Usage By Department Report, PT. Amman Mineral Nusa Tenggara.

Kimball, R., \& Ross, M. (2013) : The Datawarehouse Toolkit : The Definitive Guide to Dimensional Modelling, Third Edition, John Wiley \& Sons, Canada.

Messaging Application, https://en.wikipedia.org/wiki/Messaging_apps, accessed on September $17^{\text {th }}, 2019$. 
Telegram 200 Million Users, https://telegram.org/blog/200-million, accessed on September $17^{\text {th }}$, 2019.

Telegram (Software), https://en.wikipedia.org/wiki/Telegram_(software), accessed on September $17^{\text {th }}, 2019$. 
PROSIDING TPT XXVIII PERHAPI 2019 